\title{
Effects of ice scour on the structure of sublittoral marine algal assemblages of St. Lawrence and St. Matthew Islands, Alaska
}

\author{
John N. Heine \\ Moss Landing Marine Laboratories, PO Box 450, Moss Landing, California 95039-0450, USA
}

\begin{abstract}
Ice scour and gouging play a major role in the distribution and abundance of macroalgae and sessile invertebrates in the northern Bering Sea. Annual ice scouring and gouging create a gradient of disturbance, at one extreme removing the entire biota from horizontal rock surfaces in shallow water $(<12 \mathrm{~m})$, with a transition to a rock slope area where the effects of disturbance are less intense and more intermittent in nature. This appears to restrict adult perennial algae such as Laminaria dentigera, $L$. groenlandica, L. yezoensis, and Alaria crispa to valleys and crevices protected from ice scour Recruitment of young Laminariales was highest on the less severely scoured sloping rock surfaces between the adult populations and the ice scoured rock tops, possibly due to the gradient of disturbance. Laminaria spp. were abundant in shallow water, but below the depth of ice scouring (>12 m), Laminaria spp. were less common, and Agarum cribrosum, which was rare in shallow water, became common. Contrary to other studies, the lower distribution of $A$. cribrosum is not related to grazing sea urchins, as urchins and other large herbivores are absent. The algal zone extended to a depth of ca $28 \mathrm{~m}$, where sessile invertebrate cover became high. The marine benthos of St. Lawrence Island was characterized by a high cover of Laminaria spp., few understory algae, and sessile invertebrates such as barnacles, hydroids, mussels, sponges, and bryozoans, while St. Matthew Island had a high cover of Laminaria dentigera, abundant understory red algae such as Ptilota asplenioides, Cirrulicarpus gmelinii, and encrusting coralline algae, and fewer sessile invertebrates.
\end{abstract}

\section{INTRODUCTION}

The structure and organization of marine algal communities are poorly known in northern polar habitats. Although there are several excellent studies in the sea otter dominated kelp communities from the Aleutian Islands (Weinmann 1969, Estes \& Palmisano 1974, Dayton 1975) exploration of algal communities in the northern Bering Sea is generally limited to taxonomic descriptions (Setchell \& Gardner 1903, Shumway et al. 1964).

The northeastern Bering Sea is seasonally covered with ice as far south as the Pribilof Islands (Hood 1981). The ice begins to form in late November and break up in late May at St. Lawrence Island (LaBelle \& Wise 1983). The ice breaks along pressure zones where surface ice is forced into pressure ridges and deep ice keels form underwater. When the ice cover breaks up, these deep keels often run into the seafloor gouging extensive bottom areas (Thor \& Nelson 1981). Neushul
(1965) directly observed the violent grinding and pounding of the ice on shallow rocky shores in the Antarctic.

The majority of the work associated with ice scouring and gouging in the Arctic has focused on its extent and location with particular reference to the possible effects on man-made structures that might be placed in these areas. Ice gouging on soft-bottom substrates generally occurs in water depths of up to $30 \mathrm{~m}$, with single gouge widths of between 5 and $60 \mathrm{~m}$, multiple parallel gouge widths of $50 \mathrm{~m}$ to several $\mathrm{km}$, and gouge depths of up to $1 \mathrm{~m}$ in soft bottoms (Thor \& Nelson 1981). Josenhans (1987) reports icebergs scouring the benthos to depths of $170 \mathrm{~m}$ on the Labrador Shelf.

The ecological effects of ice scouring and gouging on benthic communities is also poorly known from northern polar waters. In Newfoundland, ice scour is temporally and spatially patchy, and was found to remove Alaria esculenta (L.) Grev. (Keats et al. 1985), resulting in ice scoured patches that were colonized by annual 
algae. Intertidal organisms appear to have refuge from ice scour in crevices in the rock and in spaces beneath and between boulders in the Pribilof Islands (O' Clair 1981). Qualitative observations in the adjacent subtidal area indicated that larger plants were found only in crevices, and that the upper surfaces of ice scoured rock were primarily occupied by filamentous green algae and small recruits of the kelp Alaria crispa Kjellman. Ice scour effects were only apparent down to a depth of $4 \mathrm{~m}$, and large perennial plants were common below that depth (O'Clair 1981).

In the Antarctic, severe ice scour has been suggested as the chief factor which controls the distribution and abundance of certain species in shallow water (Neushul 1965, DeLaca \& Lipps 1976). Qualitative observations in scoured areas indicate that algae are stunted in growth, reduced to crusts, or restricted to cracks (Delepine et al. 1966, DeLaca \& Lipps 1976, Moe \& DeLaca 1976).

The ecological effects of anchor ice growth and uplift are well known from the studies of Dayton et al. (1969, 1970). Anchor ice disturbance is different from the scouring and gouging caused by ice grounding. Large ice platelets grow on the shallow seafloor and benthic organisms to depths of as great as $30 \mathrm{~m}$. The resulting uplift causes a distinct zonation of benthic communities in McMurdo Sound (Dayton et al. 1969, 1970).

This paper describes benthic community patterns caused by ice scour and gouging in the northern Bering Sea, and presents the first quantitative description of the distribution and abundance of the common algae A more complete taxonomic and floristic treatment of the algae will be presented elsewhere (Wynne \& Heine unpubl.).

\section{MATERIALS AND METHODS}

From 6 to 25 June 1986, 28 dives were made at a variety of benthic sites on St. Lawrence and St. Matthew Islands in the Bering Sea (Fig. 1). For the community profiles of St. Matthew Island, divers started at a depth of $27 \mathrm{~m}$ and swam a straight line towards the shoreline, collecting specimens and noting the distribution and abundance of orgnaisms and physical features.

Mean density of large brown macroalgae and percent cover of common macroalgae and invertebrate groups were determined by randomly placing $1 \mathrm{~m}^{2}$ quadrats on the substrate. The number of large brown algae were counted and recorded. A random point contact (RPC) method was employed to determine the percent cover (see Foster 1975 for complete description). A $1 \mathrm{~m}$ long iron RPC bar with a string containing 5 knots on it was blindly dropped into the quadrat. The

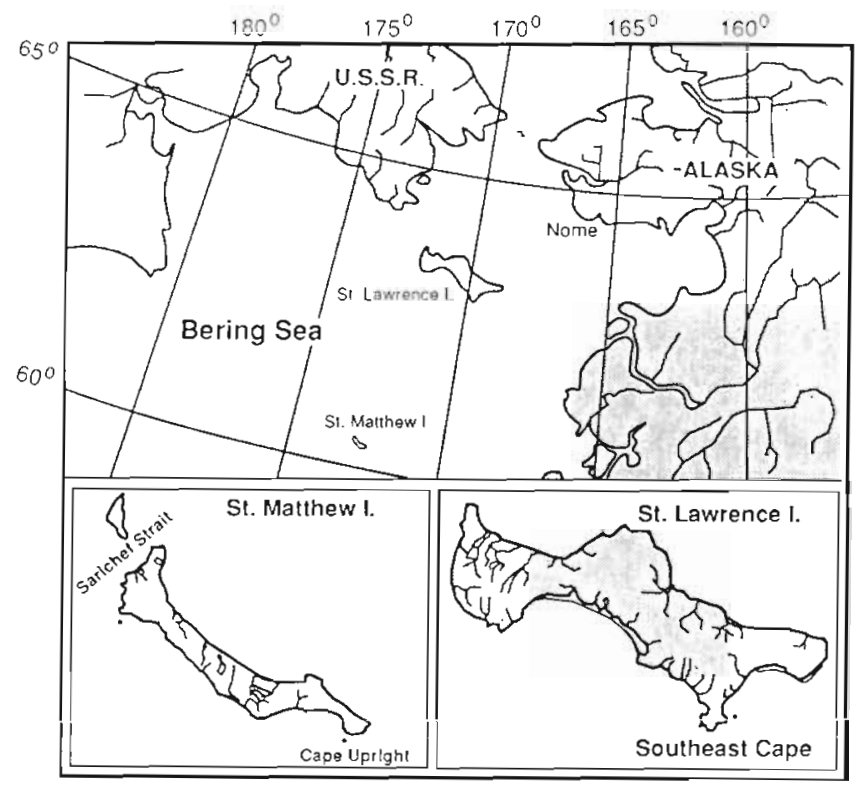

Fig. 1. Study sites at St. Lawrence and St. Matthew Islands in the Bering Sea, Alaska. Sites are marked •

string was stretched out tightly and each knot successively placed onto the substrate. If an overstory plant intersected a $1 \mathrm{~m}$ long imaginary line above the point of contact, it was recorded as a hit. Any organisms that the knots were resting on were also recorded. Hence it was possible to exceed $100 \%$ cover. Ten points were sampled per quadrat.

The density of adult and recently recruited brown macroalgae was sampled in several strata $(N=12$ at each site): ice-scoured areas, rocky slopes, protected valleys, and sand channels. Divers randomly placed $1 \mathrm{~m}^{2}$ quadrats in each area. The number of plants in each quadrat were counted and recorded.

Size frequency of the brown algae was determined in situ and in the laboratory. Adult plants were measured underwater using a fiberglass tape measure, and young recruited plants were collected from $1 \mathrm{~m}^{2}$ quadrats and measured in the laboratory immediately after the dive. Total length was measured from the top of the holdfast to the tip of the terminal blade. Voucher algal specimens were preserved in a $5 \%$ formalin solution, and later pressed. Invertebrates were fixed in $10 \%$ formalin and later transferred to $50 \%$ isopropyl alcohol.

Side-scan sonar was used to locate rocky habitats and obvious areas of ice gouging using a $100 \mathrm{kHz}$ EGG 259-4 system (Fig. 2). The tow fish, which contains the underwater transducers, was towed at a depth of ca $5 \mathrm{~m}$ above the bottom, at a constant speed, from behind the RV 'Alpha Helix'. Recordings were made on the $50 \mathrm{~m}$ range scale (see Oliver \& Kvitek 1984 for details). 


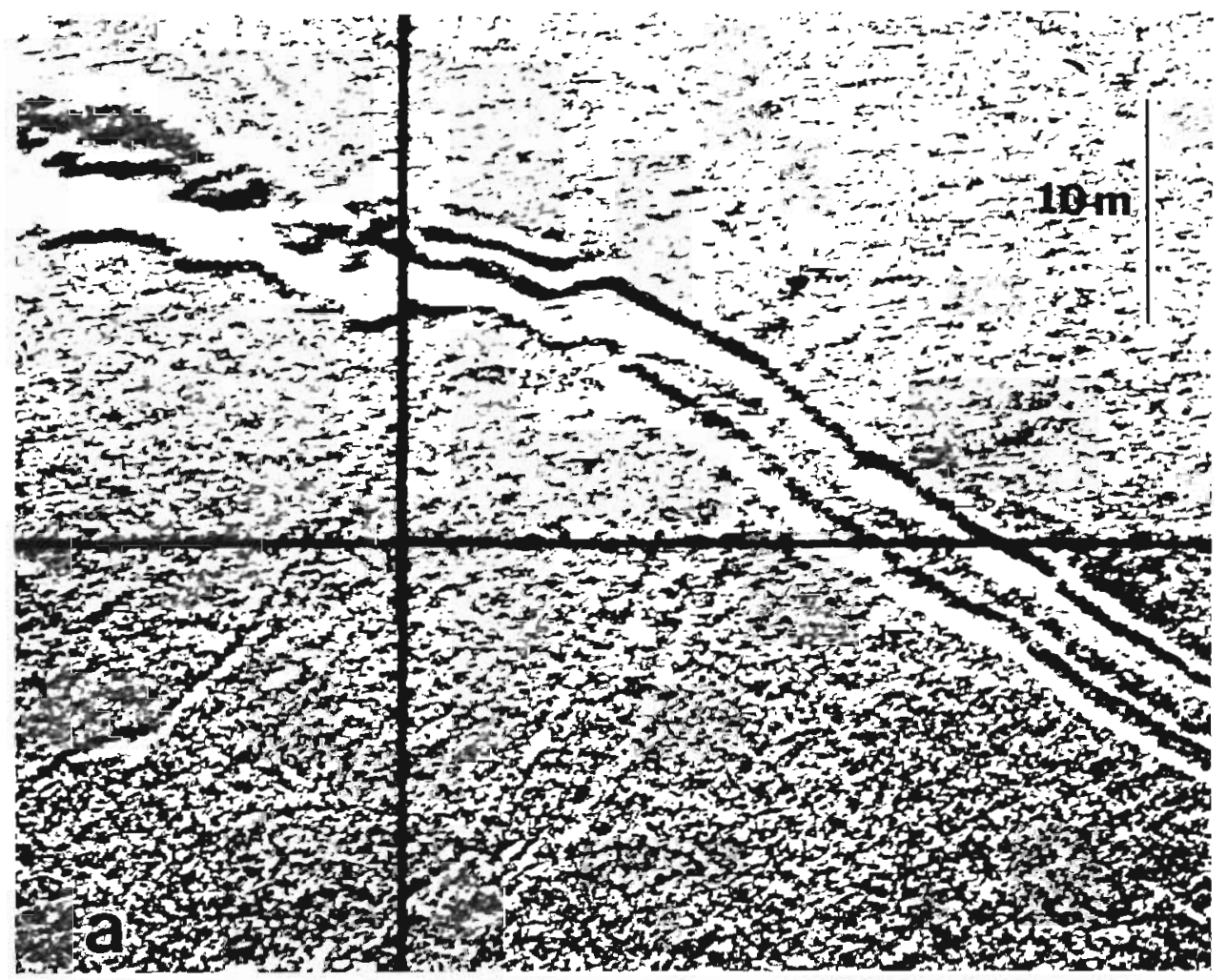

Fig. 2. (a) Side scan sonar record of ice gouging in soft bottom at a depth of $20 \mathrm{~m}$. (b) Ice-scoured horizontal rock tops showing fractures (A), and adjacent ripple marked sand and gravel bed (B) at a depth of $15 \mathrm{~m}$. From St. Matthew Island

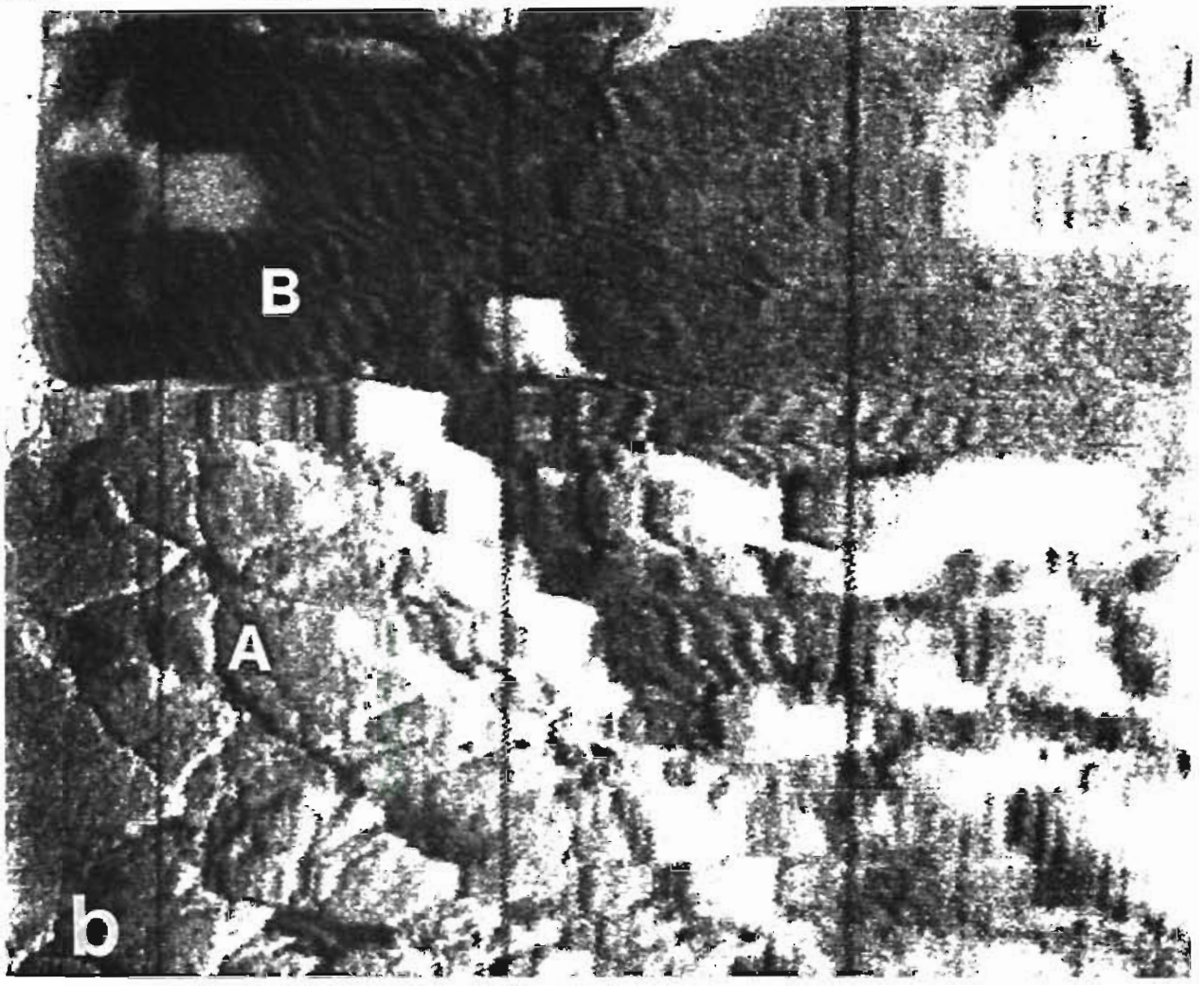




\section{RESULTS}

\section{Ice scour and gouging patterns}

Ice scouring and gouging sheared, polished, and fractured rocks depending upon the severity of impact (Fig. 2b). Diver's observations revealed that flat rock tops, many 10 to $30 \mathrm{~m}^{2}$ in area, were scoured clean of all growth, including encrusting coralline algae, at locations on each island. At. St. Lawrence Island there were no recruits or adult Alaria crispa or Laminaria dentigera on ice scoured rock tops (Table 1). The same pattern was observed for Laminaria dentigera on ice scoured rock tops at St. Matthew Island. On rock slope areas adjacent to horizontal rock surfaces, ice scour appeared to be less severe, as divers observed the presence of encrusting coralline algae and remnants of algal holdfasts and stipes that had been sheared off.

The effects of ice scour were dramatic to a depth of $12 \mathrm{~m}$ (Fig. 3). At the Southeast Cape site on St. Law-

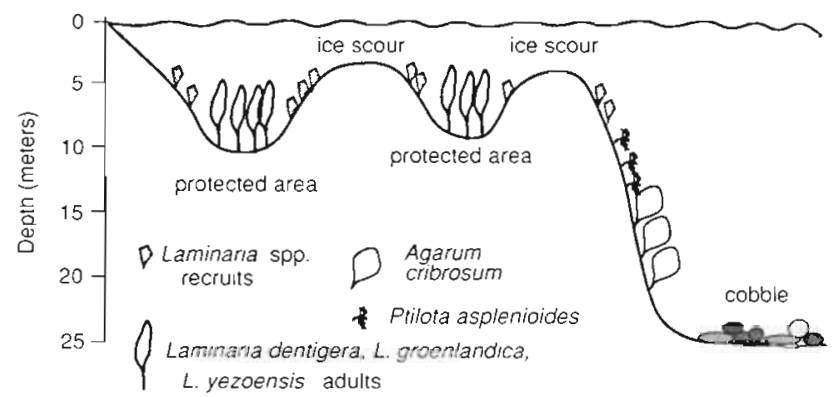

Fig. 3. Diagramatic representation of typical sublittoral habitat in areas of ice scour. Note, plant sizes are not to scale

rence Island, ice scouring was patchy and more severe compared to St. Matthew Island. Adult Alaria crispa were the only large brown algae that were abundant (mean density of $41.7 \mathrm{~m}^{-2}$ ) near ice-scoured areas
(Table 1). A very dense mixed bed of Laminaria groenlandica Rosenvinge plants (mean density of $86.1 \mathrm{~m}^{-2}$ ) that contained recent recruits as well as individuals with up to 2 seasons growth (Wilce pers. comm.) was found in the rock slope habitat.

At the Cape Upright site on St. Matthew Island a Iush bed of Laminaria dentigera Kjeliman (mean density of $15.0 \mathrm{~m}^{-2}$ ) and few Alaria crispa were present in the protected valleys and crevices between the scoured areas (Table 1). The number of recently recruited Laminariales in these protected areas was low. On the sloping rock surfaces between the protected valleys and the heavily ice scoured and gouged rock surfaces, recruits of young Laminariales recently settled in very high numbers, with a mean density of $74.3 \mathrm{~m}^{-2}$. Adult Laminariales were rare where recruitment was high on the rock slope.

Adult Laminaria dentigera from both islands showed a normal size distribution with the majority of the plants lengths between 100 and $200 \mathrm{~cm}$ (Fig. 4). A high percentage of the recruits ocurred in the smallest size category, and the percent frequency of occurrence decreased markedly with increasing size, indicating that the plants had just recently settled (Fig. 5).

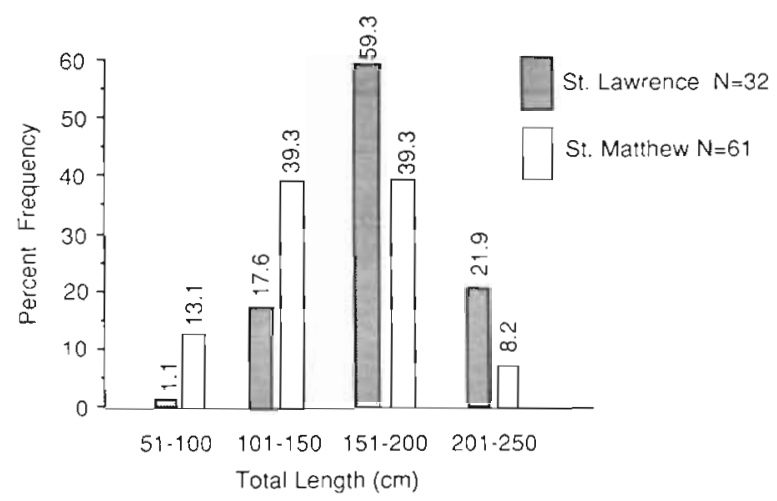

Fig. 4. Laminaria dentigera. Size frequency of adults from areas protected from ice scour

Table 1. Mean density $\mathrm{m}^{-2}$ (1 SD) of Laminariales adults and recruits in selected habitats. (1) Ice-scoured area on top of icescoured rocks, (2) rock slopes which were not ice-scoured but just below ice-scoured tops, (3) protected valleys, "crevices, or depressions most protected from ice scour, and (4) sand channels. $N=6$ for each sample

\begin{tabular}{|c|c|c|c|c|}
\hline Site and species & Ice scoured rock & Rock slope & Protected valley & Sand channel \\
\hline \multicolumn{5}{|c|}{ Southeast Cape, St. Lawrence Island } \\
\hline Alaria crispa (adults) & 0 & 0 & 0 & $41.7(10.7)$ \\
\hline $\begin{array}{l}\text { Laminaria groenlandica } \\
\text { (adults and recruits) }\end{array}$ & 0 & $86.1(27.4)$ & Habitat absent & 0 \\
\hline \multicolumn{5}{|l|}{ Cape Upright, St. Matthew Island } \\
\hline Laminaria dentigera (adults) & 0 & $0.3(0.5)$ & $15.0(4.4)$ & Habitat absent \\
\hline Laminana sp. (recruits) & 0 & $74.3(16.3)$ & $0.8(1.1)$ & Habitat absent \\
\hline
\end{tabular}




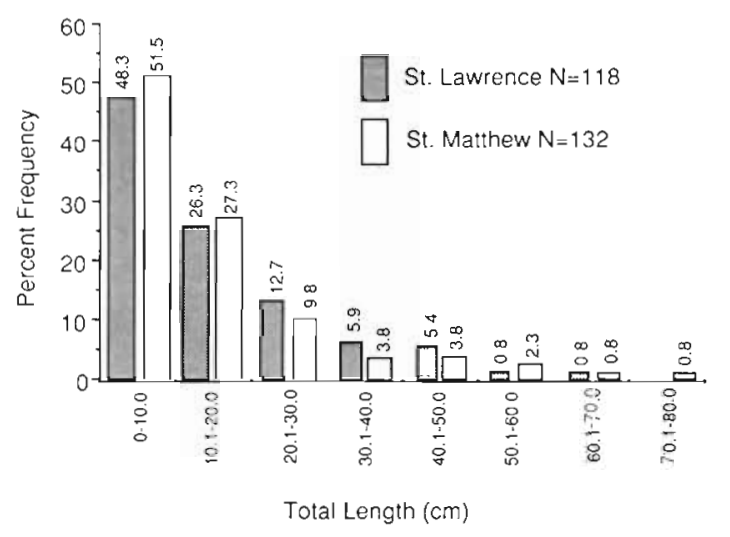

Fig. 5. Laminaria spp. Size frequency of recruits from areas adjacent to ice scour

\section{Algal and invertebrate distribution and abundance}

At the Southeast Cape site, adult Laminaria dentigera and $L$. groenlandica were numerous (mean density of $13.4 \mathrm{~m}^{-2}$ ) and covered $91 \%$ of the sea floor (Table 2). Recently recruited young Laminariales were less abundant (mean density of $5.1 \mathrm{~m}^{-2}$ ), especially in areas with a dense overstory of adult plants. Other common algae included Agarum cribosum (Mertens) Bory ( $6 \%$ cover), Odonthalia dentata (L.) Lyngb. (8\%), and encrusting coralline algae $(29 \%)$. Sessile invertebrate cover was high, consisting of barnacles (24\% cover), hydroids $(17 \%)$, mussels $(11 \%)$, and yellow sponge $(9 \%)$. Total cover was $198 \%$ due to the layering aspect of the Laminaria spp. overstory.
Two water depths were surveyed in areas devoid of ice scour effects south of Sarichef Strait on St. Matthew Island. Adult Laminaria dentigera (and a few Laminaria yezoensis Miyabe) were much more abundant in shallower water (mean density of $8.8 \mathrm{~m}^{-2}$ ) than at the deeper station (mean density of $1.8 \mathrm{~m}^{-2}$ ) (Table 3 ). Recruits were rare in deeper water (mean density of

Table 2. Mean density $\mathrm{m}^{-2}(1 \mathrm{SD})$ and percent cover of common macrophytes and invertebrate groups at Southeast Cape, St. Lawrence Island, at a depth of $8 \mathrm{~m}$, with little or no ice gouging. --: no data

\begin{tabular}{|lcc|}
\hline Species & $\begin{array}{c}\text { Density } \\
(N=25)\end{array}$ & $\begin{array}{c}\text { Percent cover } \\
(N=10)\end{array}$ \\
\hline $\begin{array}{l}\text { Laminaria dentigera } \\
\text { and L. groenlandica }\end{array}$ & $13.4(5.7)$ & 91.0 \\
Laminariales recruits & $5.1(4.8)$ & 1.0 \\
Agarum cribrosum & $1.4(2.2)$ & 6.0 \\
Odonthalia dentata & - & 8.0 \\
Encrusting coralline algae & - & 29.0 \\
Barnacles & - & 24.0 \\
Hydroids & - & 17.0 \\
Mussels & - & 1.0 \\
Yellow sponge & - & 9.0 \\
Bryozoan & - & 2.0 \\
Total cover & \multicolumn{2}{c}{$198.0 \%{ }^{\mathrm{a}}$} \\
a Total cover exceeds $100 \%$ because of layered canopy \\
\hline
\end{tabular}

$1.0 \mathrm{~m}^{-2}$ ) and slightly more abundant in shallower water (mean density of $4.0 \mathrm{~m}^{-2}$ ). Agarum cribrosum had a cover of $23.7 \%$ at the deeper station, but was not present in the shallow zone. The understory red algae

Table 3. Mean density $\mathrm{m}^{-2}$ (1 SD) and percent cover of common macrophytes and invertebrate groups at Sarichef Strait, St. Matthew Island, in areas with little or no ice gouging. Deep site is at a depth of $14 \mathrm{~m}$, and shallow site is at a depth of $8 \mathrm{~m}$

\begin{tabular}{|c|c|c|c|c|}
\hline \multirow[t]{2}{*}{ Species } & \multicolumn{2}{|c|}{ Density } & \multicolumn{2}{|c|}{ Percent Cover } \\
\hline & $\begin{array}{c}\text { Deep } \\
(N=8)\end{array}$ & $\begin{array}{l}\text { Shallow } \\
(N=10)\end{array}$ & $\begin{array}{c}\text { Deep } \\
(N=8)\end{array}$ & $\begin{array}{l}\text { Shallow } \\
(N=8)\end{array}$ \\
\hline Laminaria dentigera & $1.8(2.9)$ & $8.8(5.7)$ & 17.5 & 76.0 \\
\hline Laminariales recruits & $1.0(1.4)$ & $4.0(1.9)$ & 0 & 1.2 \\
\hline Agarum cribrosum & $4.0(2.7)$ & 0 & 23.7 & 0 \\
\hline Ptilota asplenioides & & & 50.0 & 40.0 \\
\hline Cirrulicarpus gmelinii & & & 10.0 & 7.5 \\
\hline Yendonia crassifolia & & & 5.0 & 2.5 \\
\hline Callophyllis rhynchocarpa & & & 2.5 & 6.2 \\
\hline Encrusting coralline algae & & & 43.7 & 51.2 \\
\hline Articulated coralline algae & & & 6.2 & 10.0 \\
\hline Yellow sponge & & & 8.7 & 11.2 \\
\hline Orange sponge & & & 1.2 & \\
\hline Tunicate & & & 11.2 & \\
\hline Barnacles & & & 10.0 & \\
\hline Total cover & & & $189.7 \%$ & $205.8 \%{ }^{a}$ \\
\hline
\end{tabular}


Ptilota asplenioides (Esper.) C. Ag., Cirrulicarpus gmelinii (Grunow) Tokida \& Masaki, and encrusting coralline algae were abundant in both deep and shallow water. Sessile invertebrate cover was lower than that found at St. Lawrence Island. Tunicates and barnacles were present at the deeper station, but absent in shallower water (Table 3). Total cover was slightly higher in shallower water, and was comparable to that found at Southeast Cape, St. Lawrence Island (Tables 2 and 3).

Surveys at a depth of $27 \mathrm{~m}$ at the site south of Sarichef Strait, St. Matthew Island, indicated that this was below the depth of the foliose algal zone, with a high cover of pink alcyonacean soft coral, erect bushy bryozoans, hydroids on rock edges, and a low cover of encrusting coralline algae. At a depth of $20 \mathrm{~m}$, Agarum cribrosum and foliose red algae became common (Fig. 3).

\section{DISCUSSION}

The distribution and abundance of macroalgae and sessile invertebrates in shallow water at St. Lawrence and St. Matthew Islands is strongly influenced by ice scour. Ice scouring and gouging at these sites removed the entire biota from horizontal rock surfaces at depths up to $12 \mathrm{~m}$. Adult perennial algal species are restricted to protected valleys and crevices between the flat, ice scoured rocks. The same species recruit in large numbers on the rock slopes between the protected crevices and the ice scoured rock tops.

The obvious question is why did the recruits settle only on the rock slopes, and not on the ice scoured rock tops? There appears to be a gradient of disturbance from the severe scouring and gouging of the horizontal rock tops to the less intense, intermittent scouring of the rock slope. Since the ice cover had only recently broken up, the rock tops may have been subjected to ice scour when the propagules settled, prohibiting their survival.

In other studies, Alaria fistulosa P. et R. rapidly recruited into space provided by the removal of Laminaria spp. and Agarum cribrosum canopies (Dayton 1975), and into recently ice scoured areas (O'Clair 1981). Although A. crispa adults were abundant in nearby sand channels, recruits of this species were not found in the ice scoured areas in this study, which were dominated by juvenile Laminaria spp. This may be due to intergeneric differences in spore availability at the time of the disturbance, and more detailed observations during other periods of the year might reveal different recruitment patterns.

Laminaria dentigera was abundant in shallow water at St. Matthew Island. Agarum cribrosum was most abundant in deeper water, and was rare in the shallow zone dominated by the Laminaria spp. At southern Kodiak Island, Laminaria dentigera was also abundant in shallow water to a depth of $18 \mathrm{~m}$ (Calvin \& Ellis 1978), and A. cribrosum was abundant only at the most protected sites, usually occurring in a band within the Laminaria spp. zone, but sometimes extending below it. Dayton (1975) reported a similar distribution pattern for these species, and suggested that Laminaria spp. suppresses the growth of $A$. cribrosum in shallow water, but that $A$. cribrosum was more successful in deeper water in the presence of sea urchins, which have been shown to dislike this species (Vadas 1968). As sea urchins were absent at the sites reported here, factors other than grazing must be influencing the distribution of these species.

The understory algal cover at St. Matthew Island was much more extensive than that at St. Lawrence Island, with a total combined cover of $117 \%$, and sessile invertebrate cover was low. This may be related to reduced ice formation and scour with decreasing latitude. Although there are no data available for seasonal variations in underwater light levels, our observations from past visits indicate that water visibility was consistently better at St. Matthew Island, averaging 5 to $10 \mathrm{~m}$, and light levels were appreciable down to depths of $20 \mathrm{~m}$.

The diversity of algae on St. Lawrence Island was relatively low. There was a distinct lack of understory foliose algae, a relatively low cover of coralline algae, and a high cover of sessile invertebrates. The more severe ice scour at this island may prevent the establishment of understory algal beds and favor the more resilient sessile invertebrate forms found. A similar pattern was observed in the Antarctic, where species diversity was higher in areas where ice scour sheared off the Desmarestia menziesii canopy, opening up space for red algae and invertebrates (DeLaca \& Lipps 1976).

It is conceivable that ice cover and extended periods of darkness at the latitude of St. Lawrence Island prohibit the extensive development of a red algal understory. Laminaria solidungula grows most rapidly in complete winter darkness under the ice canopy by utilizing stored food reserves (Chapman \& Lindley 1980, Dunton 1985). However, for other non-Laminarian algal species, no growth would be expected under snow-covered ice (Healy 1972). Although dredge samples in the more northerly Beaufort Sea have produced a variety of seaweeds (Mohr et al. 1957), algal stands are largely absent from the perimeter of the northern Bering Sea (Dall 1875). This may be due in large part to the sedimentation and silting effects of sea ice (MacGinitie 1955), which may hinder the establishment and development of sporophytes. 
Below the depth of ice gouging (>12 m), algae were more common on horizontal surfaces, and sessile invertebrates covered vertical walls. Below the algal zone (ca $>27 \mathrm{~m}$ ), some rocky areas were characterized by large (up to $30 \mathrm{~m}^{2}$ ) patches of pink alcyonacean soft coral, erect bushy bryozoans, hydroids, and sponges. Motile invertebrates and fishes were absent, except a few sea stars and king crabs. This conspicuous lack of grazers suggests that the lower limit of algal distribution may be influenced by a lack of light and by competition for space with sessile invertebrates (Foster \& Schiel 1985).

The kelp forests of Amchitka Island, which are inhabited by sea otters that effectively remove many of the large herbivores, are characterized by a surface canopy of Alaria fistulosa and subsurface canopies of Laminaria species and Agarum cribrosum (Dayton 1975). Competitive effects on the distribution of these large kelps have been demonstrated experimentally. Dayton (1975) also suggests that the lower distribution of these kelps appears to be primarily limited by sea urchin grazing. As sea urchins and other herbivores were not found in this study, the lower limit of distribution of the kelps is most likely determined by the lack of light.

A gradient of disturbance exists on both a latitudinal and microhabitat scale. General observations indicated that ice scouring and gouging was more severe to the north at St. Lawrence Island, where algal diversity was low, and less severe to the south at St. Matthew Island, where diversity was higher, supporting current disturbance theory (Connell 1978, Sousa 1984). Ice gouging also limits the distribution of adult Laminaria spp. and Alaria crispa to protected microhabitats. A. crispa does not form a surface canopy (pers. obs.), and a more distinct separation of Laminaria spp. and Agarum cribrosum populations exist. Whereas Alaria fistulosa was characterized as a fugitive species which rapidly colonized areas artificially cleared of the dominant Laminaria spp. canopy at Amchitka (Dayton 1975), this was not the case in the natural clearing caused by ice gouging in the northern Bering Sea.

Acknowledgements. I thank J. Oliver for his ideas and the opportunity to work in the Bering Sea, and S. Kim, M. Silberstein and A. Dauben for diving assistance. M. Foster, J. Oliver, J. McClintock, S. Kim, R. Kvitek and 2 anonymous reviewers made helpful suggestions on the manuscript, and L. McMasters helped with some of the graphics. I am very grateful to $\mathrm{M}$. Wynne and $\mathrm{R}$. Wilce for taxonomic assistance with the algae. The USGS kindly lent the use of the side scan sonar system. Special thanks go to the crew of the RV 'Alpha Helix' for their hard work. This work was partially supported by grants to J. Oliver from the National Science Foundation (DPP-8512757) and from the National Geographic Society.

\section{LITERATURE CITED}

Calvin, N. I., Ellis, R. J. (1978). Quantitative and qualitative observations of Laminaria dentigera and other subtidal kelps of southern Kodiak Island, Alaska. Mar. Biol. 47; 331-336

Chapman, A. R. O., Lindley, J. E. (1980). Seasonal growth of Laminaria solidungula in the Canadian high arctic in relation to irradiance and dissolved nutrient concentrations. Mar. Biol. 57. 1-5

Connell, J. H. (1978). Diversity in tropical rain forests and coral reefs. Science 199: 1302-1310

Dall, W. H. (1875). Arctic marine vegetation. Nature, Lond. 12 : 166

Dayton, P. K. (1975). Experimental studies of algal canopy interactions in a sea otter dominated kelp community at Amchitka Island, Alaska. Fish. Bull. U.S. 73: 230-237

Dayton, P. K., Robilliard, G. A., DeVries, A. L. (1969). Anchor ice formation in McMurdo Sound, Antarcitca, and its biological effects. Science 163: 273-275

Dayton, P. K., Robilliard, G. A., Paine, R. T (1970). Benthic faunal zonation as a result of anchor ice at McMurdo Sound, Antarctica. In: Holdgate, M. (ed.) Antarctic ecology. Academic Press, London, p. 244-258

DeLaca, T E., Lipps, J. H. (1976). Shallow-water marine associations, Antarctic peninsula. Antarctic J. U.S. 11: $12-20$

Delepine, R., Lamb, M., Zimmermann, M. H. (1966). Preliminary report on the marine vegetation of the Antarctic peninsula. Proc. Int Seaweed Symp. 5: 107-116

Dunton, K. H. (1985). Growth of dark-exposed Laminaria saccharina (L.) Lamour and Laminaria solidungula J. Ag. (Laminariales: Phaeophyta) in the Alaskan Beaufort Sea. J. exp. mar. Biol. Ecol. 94: 181-189

Estes, J. A., Palmisano, J. F. (1974). Sea otters: their role in structuring nearshore communities. Science 185: $1058-1060$

Foster, M. F. (1975). Algal succession in a Macrocystis pyrifera forest. Mar, Biol. 32: 313-329

Foster, M. F., Schiel, D. R. (1985). The ecology of giant kelp forests in California: a community profile. U.S. Fish Wildl. Serv. Biol. Rep. 85 (7.2) p. 1-152

Healy, F. P. (1972). Photosynthesis and respiration of some Arctic seaweeds. Phycologia 11 (3/4): 267-271

Hood, D. W. (1981). Introduction. In: Hood, D. W. Calder, J. A. (eds.) The Eastern Bering Sea Shelf: oceanography and resources, Vol. I. NOAA, US Dept of Commerce, p. XIII-XVIII

Josenhans, H. (1987). Icebergs scour the ocean floor. Geos (16) $4: 1-5$

Keats, D. W., South, G. R., Steele, D. H. (1985). Algal biomass and diversity in the upper subtidal at a pack-ice disturbed site in eastern Newfoundland. Mar. Ecol. Prog. Ser 25: $151-158$

LaBelle, J. C., Wise, J. L., (1983). Alaska marine ice atlas. Arctic Environmental Information and Data Center, University of Alaska, Anchorage

MacGinitie, E. G. (1955). Distribution and ecology of the marine invertebrates of Point Barrow, Alaska. Smithson. misc. Collect. Vol. 128, No. 9

Moe, R. L., DeLaca, T. E. (1976), Occurrence of macroscopic algae along the Antarctic peninsula. Antarctic J. U.S. 11: $20-24$

Mohr, J. L., Wilimovsky, N. J., Dawson, E. Y. (1957). An arctic Alaskan kelp bed. Arctic 10(1): 45-52

Neushul, M. (1965). Diving observations of sub-tidal Antarctic marine vegetation. Botanica mar. 8: 234-243 
O'Clair, C. E. (1981). Disturbance and diversity in a boreal marine community: the role of intertidal scouring by sea ice. In: Hood, D. W., Calder, J. A. (eds.) The Eastern Bering Sea Shelf: oceanography and resources, Vol. II, NOAA. US Dept of Commerce, p. 1105-1130

Oliver, J. S., Kvitek, R. G. (1984). Side-scan sonar records and diver observations of the gray whale (Eschrichtius robustus) feeding grounds. Biol. Bull. mar. biol. Lab., Woods Hole 167: 264-269

Setchell, W. A., Gardner, N. L. (1903). Algae of Northwestern America. Botany, Vol. 1. University of California Publ., Berkeley, p. 165-418

Shumway, G., Moore, D. G., Dowling, G. B. (1964). Fairway

This article was submitted to the editor
Rock in Bering Strait. In: Miller, R. L. (ed.) Papers in marine geology. MacMillan, New York, p. 401-407

Sousa, $W$ P. (1984). The role of disturbance in natural communities. A. Rev. Ecol. Syst. 15: 353-391

Thor, D. R., Nelson, C. H. (1981). Ice gouging on the subarctic Bering shelf. In: Hood, D. W., Calder, J. A. (eds.) The Eastern Bering Sea Shelf: oceanography and resources, Vol. I. NOAA, US Dept. of Commerce, p. 279-291

Vadas, R. L. (1968). The ecology of Agarum and the kelp bed community. Ph.D. thesis, Univ. of Washington, Seattle

Weinmann, F. C. (1969). Aspects of benthic marine algal ecology at Amchitka Island, Alaska. Battelle Memorial Institute, Columbus Laboratories

Manuscript received: August 12, 1988

Revised version accepted: December 22, 1988 